\title{
Jacek Guliński
}

\section{Od reformy do reformy}

STRESZCZENIE. W artykule przedstawiono trzy zagadnienia będące ważnymi elementami dyskusji w ramach nowej reformy szkolnictwa wyższego w Polsce. Autor omówił sprawy wyborów/konkursów na stanowisko rektora, relacje organów jednoosobowych z organami kolegialnymi uczelni oraz zagadnienia kontaktów uczelni z gospodarką, głównie w kontekście komercjalizacji wyników prac badawczych.

SŁOWA KLUCZOWE: sektor nauki, szkolnictwo wyższe, wybory rektora, organy jednoosobowe, organy kolegialne, komercjalizacja wyników prac badawczych, transfer technologii

\section{Wstęp}

Nowa konstytucja dla nauki - jeden z filarów reformy nauki i szkolnictwa wyższego w Polsce, zwanej przez samego autora reformą Gowina, jest bez wątpienia zmianą oczekiwaną przez świat nauki i szkolnictwa wyższego od wielu lat. Oczekiwaną często obiektywnie, bo zmienia się świat i Europa, rola i zadania nauki i sektora szkolnictwa wyższego. Niestety ciągłe nowelizacje „starej” ustawy Prawo o szkolnictwie wyższym (jakkolwiek mające za zadanie sprostać nowym wyzwaniom, zadaniom oraz oczekiwaniom środowiska) oraz pozostałych aktów prawnych doprowadziły do nadregulacji i utraty ich przejrzystości. Reforma Barbary Kudryckiej wprowadziła wiele istotnych zmian do ustaw regulujących polską naukę i szkolnictwo wyższe, idących w dobrym kierunku (w tym: podniesienie jakości nauczania, doskonałość naukowa, umiędzynarodowienie nauki i szkolnictwa wyższego, działania wspierające komercjalizację wyników prac badawczych czy wpływające na rozwój innowacyjnej gospodarki). Jednak nie przekonały one większości społeczności 
akademickiej w kraju do zmiany swoich postaw. Przeciwnicy reformy wykorzystali nadmierną biurokrację jako oręż do walki z ideą podwyższenia jakości swojej pracy dydaktycznej, zbyt daleko posuniętą „punktozę” do oporu przeciwko ocenie i wartościowaniu efektów ich pracy naukowej (poziom publikacji i innych rezultatów nauki) a kuriozalne, w szczegółowych rozwiązaniach, uwłaszczenie uczonych na ich wynikach aplikacyjnych przeciwko idei komercjalizacji rezultatów badań oraz większego otwarcia uczelni na środowisko społeczne i gospodarcze. W ten sposób sensowne skądinąd postulaty ugrzęzły w gąszczu rozporządzeń i rozwiązań szczegółowych i nie zyskały aprobaty ani większości kierownictw uczelni, ani ich społeczności. A my na uczelniach odetchnęliśmy z ulgą. Znowu się udało i za wiele nie trzeba zmieniać. Oczywiście ten obraz nie jest do końca prawdziwy. W pewnym sensie zaczęto jednak bardziej doceniać tych, których dorobek naukowy ma odniesienie międzynarodowe. Oczywiście zmieniły się programy studiów i sylabusy. Projekty finansowane przez rządowe agencje - przebudowany NCBiR oraz nowo utworzony NCN - stały się coraz powszechniejsze w środowisku, tu i ówdzie potrzeby gospodarki zaczęły interesować uczonych. Trzeba jednak przyznać, że w ramach obowiązującego dziś i wczoraj prawa zarówno uczelnie, jak i inne instytucje sektora nauki mogły podjąć o wiele bardziej efektywne wysiłki na rzecz racjonalizacji swoich zachowań i sensownej odpowiedzi na skądinąd bezdyskusyjną konieczność zmian, zarówno w obszarach wymienionych wyżej, jak i wielu innych. I co jest jednak pocieszające, kilka, kilkanaście uczelni podjęło to wyzwanie... I w mojej opinii wyprzedzają tym samym pozostałych.

W założeniach reformy Gowina przyjmuje się niepisaną zasadę, że sektor nauki w kraju to sektor szkolnictwa wyższego. A przecież to nie jest prawda! W zależności od wykorzystanych danych statystycznych z GUS można udowodnić, że 70-75\% czy nawet $80 \%$ publicznej nauki w Polsce uprawia się w szkołach wyższych. Natomiast brakujące 20-30\% to rzesza instytucji - instytutów Polskiej Akademii Nauk, instytutów badawczych i innych aspirujących do tego grona. Poza tym sektor gospodarki prowadzi badania, i to na skalę finansową porównywalną z nakładami budżetowymi (samego państwa, jak i Unii Europejskiej), dokładając się w 50-60\% do zawstydzająco niskich sumarycznych nakładów na badania i rozwój w kraju. A intensywność badań prowadzonych w sektorze gospodarki powinna wzrastać znacząco, aby przykładać się do innowacyjnego rozwoju gospodarczego, lansowanego chociażby w strategii Morawieckiego. Swoją drogą każdy rząd ma innowacyjny rozwój gospodarki na pierwszym planie. Czasami tylko postulatywnie, ale jednak...

Nie można zmienić sektora nauki w Polsce, ustalając jedynie nowy porządek dla szkół wyższych! Nie słychać za wiele o reformie Polskiej Akademii Nauk (poza dyskusyjnymi i iluzorycznymi pomysłami przekształcenia Akademii w Super Uniwersytet). Trzeba sobie jasno powiedzieć, że ten filar polskiej nauki skutecznie przez ostatnie lata opiera się jakiejkolwiek poważniejszej reformie. Rozwiązania, które jeszcze pokutują w polskim PAN-ie, uległy znaczącej zmianie w krajach Eu- 
ropy Środkowo-Wschodniej, w tym sąsiadujących z nami. Nie potrafimy wyciągać wniosków, nie chcemy konfliktować środowiska, nie ma woli politycznej? Instytuty badawcze poddawane są reformie $\mathrm{w}$ postaci konsolidacji najlepszych (trochę na siłę) w Narodowy Instytut Technologiczny. Póki co bronią się one przed realizowaną krok po kroku zmianą. Przynajmniej część podnoszonych argumentów wymaga otwartej debaty i osiągnięcia konsensusu. Na pierwszy rzut oka bardziej widoczna jest determinacja resortu do wprowadzania reform niż otwarcie na kompromis w tej sprawie. A pozostałe instytuty mają się sprawdzić same na rynku badań i komercjalizacji wyników badań. Przedsiębiorstwa będą motywowane do nakładów na badania i rozwój zwolnieniami podatkowymi (mała i duża ustawa dotycząca innowacyjności). Jest to postulowane już od wielu lat. Dobre praktyki krajów OECD wskazywały, że nie ma tu innej drogi. Opory Ministerstwa Finansów i prymat unijnej procedury nadmiernego deficytu uniemożliwiały wprowadzenie sensownych rozwiązań przez poprzednią ekipę rządzącą. Na szczęście zrobiono wreszcie krok w dobrym kierunku. Nadzór właścicielski w spółkach skarbu państwa także nie potrafil przez ostatnie lata znacząco podnieść wydatków na B+R w tej grupie przedsiębiorstw. A tutaj relatywnie łatwo zwiększyć te nakłady. Zapowiadane są zmiany w tym zakresie. Poczekamy, zobaczymy...

Problemy polskiej nauki to problemy publicznego i niepublicznego sektora nauki i relacji między nimi. Nowa Ustawa 2.o tego nie zmieni, nawet najlepiej sformułowana będzie dotyczyła tylko wycinka. Najistotniejszego, ale nie całości. Istotne dla rozwoju szkół wyższych są moim zdaniem zagadnienia sposobu wyłaniania rektorów/dziekanów, podziału zadań pomiędzy organy jednoosobowe i kolegialne na uczelni oraz relacje uczelni z gospodarką w kontekście komercjalizacji wyników prac badawczych. Przynajmniej wydaje mi się, że w tych obszarach mam jakieś rozeznanie i własny, czasem dosyć wyrazisty, by nie powiedzieć kontrowersyjny osąd.

\section{Rektor wybierany przez elektorów czy z konkursu?}

Jedną z głównych tradycji szkolnictwa wyższego w Polsce jest tryb wyłaniania Rektora. Jako „pierwszy wśród równych” wybierany jest on ze środowiska w procesie wyborczym, który reguluje po części ustawa, a po części obyczaj, tradycja. W imię tych wartości można - jak uważa część konserwatywna akademickiej społeczności (czyli jej znakomita większość) - w ogóle nie podejmować dyskusji na temat zmiany tego odwiecznego rytuału. Tylko czy taka postawa gwarantuje bezpieczeństwo i spokój profesorom, a uczelni optymalne przywództwo?

Przyjrzyjmy się bliżej kulisom tego procesu wyborczego. Rady Wydziałów (często pod kontrolą dziekana) wybierają swoich elektorów. Elektorami są również przedstawiciele pracowników niebędących nauczycielami akademickimi (często manipulowani przez władze administracyjne uczelni). No i duża, ważna grupa gło- 
sów elektorskich - studenci. Oczywiste, że powinni oni mieć wpływ na wybór rektora, ale mało kto zdaje sobie sprawę, w jaki sposób są oni powoływani, w jakim stopniu rzeczywiście reprezentują swoje środowisko i jak bardzo są manipulowani przez innych aktorów uczelnianego środowiska. Mamy więc wybrane zgodnie z prawem ciało elektorskie - kolegium elektorskie. Wbrew pozorom skład tego kolegium jest bardzo ważny, kandydaci na rektora muszą wykonać dużą pracę na etapie ich powoływania, w momencie, w którym nie mówi się jeszcze o osobowych kandydaturach. Zakulisowe rozmowy potencjalnych kandydatów z dziekanami, reprezentantami uczelnianej administracji i przedstawicielami Samorządu Studenckiego są kluczowe i decydują o wyniku wyborów, które jeszcze daleko przed nami. Potem dopiero zgłaszane są oficjalne kandydatury i zaczyna się kilkutygodniowa kampania wyborcza na uczelni. Kandydaci na rektora przekonują dziekanów i grono elektorów z ich wydziałów do swojego programu (wykazując ewentualne profity dla nich na przyszłość) oraz dobierając z ich „terenu” prorektorów jako efekt swoistej synergii i wdzięczności za poparcie w głównej, rektorskiej batalii. Uczelnia ma dużo szczęścia, gdy kandydat na prorektora ma zdolności i kompetencje w obszarze, w którym będzie wspierał rektora. Ale, uwaga, to najczęściej nie one decydują o wyborze prorektorskiej kandydatury. Szczególny „teatr wyborczy” odbywa się między reprezentacją studentów a kandydatem na rektora. Studenci, co naturalne, mają oczekiwania i żądania dotyczące ich statusu materialnego, organizacji życia kulturalnego czy sportowego oraz procesu dydaktycznego. I to najczęściej nie są postulaty prowadzące do podniesienia jakości procesu dydaktycznego a propozycja zmian w regulaminie studiów, które ułatwiają studenckie życie. Kandydat na rektora musi więc „coś” obiecać albo honorowo rezygnuje z 20-25\% głosów elektorskich. Kogo na to stać? Kandydat, który najlepiej upora się z tymi trudnymi wyborczymi okolicznościami, zostaje ostatecznie wybrany na rektora. Zakładamy, że sprawny i inteligentny negocjator wyborczy, prezentujący określony program, będzie najlepszy na stanowisku rektora uczelni. Naiwni są kandydaci, którzy otwarcie prezentują swój program koniecznych zmian na uczelni. A zmiany są bolesne i kosztują. Tacy kandydaci rzadko wygrywają. Zwyciężają najczęściej kandydatury stateczne, wyważone, szanujące tradycję i konserwatywne, czyli takie, które odpowiadają najbardziej starszej części profesury. Albo tacy, co nie ujawniają swoich planów dotyczących ewentualnych reform. Zwróćmy uwagę, że kolegium elektorskie reprezentuje głównie interesy starszych profesorów, którzy dość alergicznie reagują na konieczność wprowadzania zmian, czując zarazem na plecach oddech młodego pokolenia uczonych. Bezpieczeństwo, spokój, kontynuacja tradycji, etos - to są wartości, którymi szermują, i to skutecznie. Mam oczywiście świadomość, że nieco przerysowałem ten obrazek. Zgoda, że są uczelnie, gdzie to wygląda o wiele lepiej, bardziej zdroworozsądkowo. Ale czy jest ich tak wiele?

A teraz postawmy sobie uczciwe pytanie - czy akt wyborczy kolegium elektorskiego kończy się wyborem najbardziej odpowiedniej osoby do sprawowania 
funkcji „Magnificencji” i co za tym idzie - wyboru optymalnego zespołu rektorskiego do zarządzania uczelnią? Czy jesteśmy w stanie w trakcie takich wyborów ocenić i przekonać się, że osoba kandydująca do godności rektora ma zdolności do zarządzania (ew. ciągłego zarządzania zmianą, bo do tego sprowadza się obecnie zarządzanie szkołą wyższą) potężnym zespołem ludzkim, czy podejmuje się tego wyzwania z odpowiedzialnością wobec siebie i swojej instytucji, czy posiada cechy osobowe/charakterologiczne konieczne w kontaktach ze światem zewnętrznym (politycy, pracownicy ministerstwa, władze rządowe i samorządowe), łatwość posługiwania się kilkoma językami obcymi, wreszcie warunki zdrowotno-rodzinne, umożliwiające mu prawie 24-godzinną dyspozycyjność i służbę dla swojej instytucji? Czy nasz rektor potrafi delegować zadania najbliższym współpracownikom, ufać im i jednocześnie ich rozliczać, odpowiadać stanowczo „nie” największym uczelnianym autorytetom, jeśli ich interes nie współgra, niestety (a tak jest często), z interesem uczelni? Moim zdaniem proces wyborczy na uczelni może prowadzić do wyboru optymalnego kandydata spośród pretendujących - może, ale nie musi. Pozostaje pytanie, czy nawet wybór optymalnego kandydata daje szansę Uczelni na rozwój, na zmiany, na konkurencję z innymi...

A może trzeba zorganizować na uczelni ciało elekcyjne (z udziałem fachowców z zewnątrz) i ogłosić konkurs na rektora, przedstawiając warunki brzegowe. Niech wygra ten, kto najlepiej wypadnie na „przesłuchaniu”, wykaże się zdolnościami i kompetencjami, które wcześniej zostaną określone, i tymi, które będą ponad miarę. Przedstawi program rozwoju uczelni, który będzie odpowiadać strategii jej rozwoju. Sam dobierze sobie prorektorów zgodnie z ich kompetencjami i doświadczeniem, a nie w wyniku układów z poszczególnymi wydziałami. Będzie miał wpływ na wyniki konkursów na dziekanów, bo razem z nimi będzie stanowił władze wykonawczą i operacyjną uczelni. Nie znamy ostatecznych rozwiązań, które będą treścią nowej ustawy. $\mathrm{Z}$ wypowiedzi przedstawicieli kierownictwa ministerstwa można wyciągnąć wniosek, że pozostaną wybory, ale organizowane przez inne ciało elektorskie niż dotychczas. Może wprowadzi się osoby z zewnątrz (oby to nie byli politycy!), może zmieni się reguły. Zaproponowana w obecnej, obowiązującej jeszcze ustawie idea konkursów się nie przyjęła - w Polsce odbył się tylko jeden konkurs na rektora! Politycznie uzasadniona będzie jedynie modyfikacja trybu wyborczego. Nikt nie zaryzykuje rozwiązania dalej idącego. A szkoda...

\section{Organy jednoosobowe vs. kolegialne na uczelni}

Od lat na uczelni działają organy jednoosobowe - najczęściej wybierane na uczelni zgodnie z określoną procedurą wyborczą (rektor, prorektorzy, dziekani, dyrektorzy instytutów) równolegle z reprezentacją poszczególnych grup akademickiej społeczności (Senat, Rada Wydziału, Rada Instytutu). W różnych latach, zgodnie z obowią- 
zującymi w danych okresach przepisami ustawowymi i uczelnianymi procedurami, pozycja tych organów i ich wzajemne relacje ulegały zmianie.

Senat stanowi reprezentację całej społeczności akademickiej i zależnie od sytuacji (składu, świadomości członków, poczucia odpowiedzialności za instytucję - uczelnię) może „dyscyplinować” rektora i jego ekipę oraz wpływać na operacyjną działalność uczelni. Jednocześnie odpowiedzialność prawna i dyscyplinarna za wiele decyzji spoczywa na rektorze (zgodnie z ustawą) i wyłącznie na nim. Myślę, że większość rektorów nie ma pojęcia, jak ogromna jest to odpowiedzialność. Zależnie od polityki rektora Senat może być albo nie być informowany o ważnych szansach i zagrożeniach. Członkowie Senatu mający świadomość swojej roli, a zarazem jednostki odpowiedzialne mogą „uprzykrzyć” rektorowi życie, ale najczęściej przyjmują postawę bierną i mało zaangażowaną. Może to być pozytywne dla rektora, ale czasem niezbyt fortunne dla uczelni. Zatem relacje między rektorem a Senatem są wypadkową wielu czynników. W dużym stopniu operacyjność dziekana i Rady Wydziału zależy także od pozycji i stylu zarządzania dziekana oraz uległości reszty profesury zasiadającej w Radach. Wiele niepopularnych posunięć dziekan może zwekslować na decyzję Rady. Wszystko zależy od znajomości lub nieznajomości przepisów (przez dziekana i rektora), stylu przywództwa, świadomości interesów instytucji (wydziału) oraz poszczególnych pracowników.

Wydaje się, że w nowym ustroju uczelni trzeba wzmocnić role organów jednoosobowych. Jednoznacznie trzeba określić zadania dla Senatu i rektora, Rady Wydziału i dziekana. Z nowymi uprawnieniami organów jednoosobowych powinny kojarzyć się odpowiedzialność za decyzje i przejrzystość zarządzania. Dotyczy to zarówno rektora, jak i dziekana czy dyrektora instytutu. Wszystko wskazuje na to, że takie zapisy znajdą się w przyszłej ustawie. Wbrew pozorom wzmocnienie organów jednoosobowych ma sens jedynie wtedy, gdy wybór na te stanowiska zastąpimy sensownie przeprowadzonym konkursem.

\section{Kontakty uczelni z gospodarką, komercjalizacja wyników prac badawczych}

Od ponad 25 lat wszyscy politycy mówią o konieczności wzmocnienia relacji uczelni z gospodarką, zarówno w procesie dostarczania wykształconych kadr dla gospodarki, jak również roli badań i ich wyników w modernizacji naszej gospodarki. Po boomie demograficznym i potężnej fali studentów 10-15 lat temu, która przelała się przez setki publicznych i prywatnych szkół wyższych w naszym kraju, nadszedł czas na realizacje trzeciej misji uczelni, czyli na bliskie relacje szkół wyższych z otoczeniem społecznym i gospodarczym. Mając możliwość obserwowania tego typu aktywności polskich uczelni w ostatnich latach, muszę stwierdzić, że postępy w tym obszarze są niewielkie. Uczelnie nadal stanowią biurokratyczne 
machiny, które z natury rzeczy są nieprzyjazne wobec rynkowo jednak (jak można byłoby zakładać inaczej) zorientowanych przedsiębiorców. Tworzone na uczelniach rady gospodarcze i konwenty - platformy dyskursu z przedsiębiorstwami - jeżeli działają, to rzadko i jedynie w obszarze uzgadniania programów praktycznych kierunków studiów. W sumie najczęściej nie są traktowane ani przez władze uczelni, ani przedstawicieli świata gospodarczego jako narzędzia realnych kontaktów nauki z gospodarką. Uczelniane Centra Transferu Technologii tylko w niektórych uczelniach (szczególnie, co naturalne, technicznych) realizują swoją misję. W większości wypadków zatrudniają zbyt słabo wykształconych w tym celu pracowników (brokerzy technologii), zajmują się różnymi zadaniami niemającymi wielkiego związku z transferem technologii. Działalność CTT w obszarze komercjalizacji bezpośredniej (licencje, sprzedaż patentów) nie zadowala - w skali kraju liczba wszystkich udzielonych licencji czy sprzedanych praw do patentów rocznie jest porównywalna z analogiczną liczbą dla pojedynczego, dobrego brytyjskiego uniwersytetu. Co prawda uruchomiono ostatnio w kraju wiele spółek celowych uczelni do przeprowadzania komercjalizacji pośredniej, jednak ich liczba nadal nie odpowiada potencjałom badawczym czy komercjalizacyjnym uczelni, szczególnie tych technicznych. Wprowadzony kilka lat temu wymóg przygotowania przez uczelnie regulaminu korzystania z własności intelektualnej oraz regulaminu wykorzystania aparatury badawczej $\mathrm{w}$ relacji $\mathrm{z}$ otoczeniem gospodarczym został na uczelniach spełniony. Powstaje pytanie, czy jest on rozpowszechniony, znany pracownikom i stosowany w praktyce. Podejrzewam, że najczęściej były to działania fasadowe. Jak to zmienić?

Trzeba wyraźnie powiedzieć, że przychody finansowe z komercjalizacji nawet na najbardziej w nią zaangażowanych uczelniach europejskich nie przekraczają kilku procent całkowitego budżetu. Nie robimy więc tego dla zysku, tylko z powinności wobec społeczeństwa i gospodarki, które płacąc podatki, utrzymują sektor nauki i szkolnictwa wyższego. Świadomość wagi i wartość potencjału intelektualnego uczelni, praw własności intelektualnej czy przemysłowej jest w naszym środowisku drastycznie niska. Wielu profesorom ciągle wydaje się, że mają wszelkie prawa do rezultatów prowadzonych badań bez względu na to, kto finansował badania i kto brał w nich udział. Część z nich dysponuje uczelnianym sprzętem i aparaturą jak własnym dobrem. Stan inwentarzowy zakładu/instytutu mylą ze spisem dóbr osobistych. I to są jedne z głównych barier w kontaktach z gospodarką. Przedsiębiorcy indywidualnie docierają do niezorientowanych lub zorientowanych tylko na swoje dochody pracowników uczelni, oferując im śmieszne - z ich perspektywy - wynagrodzenia za konsultacje czy ekspertyzy. Uczelnia najczęściej nie bierze udziału w negocjacjach co do ceny, a często nawet nie ma pojęcia o tych kontraktach. Ciekawe, że w brytyjskich czy niemieckich uczelniach to jest niemożliwe. Na drodze stoją regulacje i etos zawodowy. A u nas?

Czy nowa Ustawa 2.0 ma szansę zmienić ten stan rzeczy? Nie wydaje się... Wszystko wskazuje na to, że w nowej ustawie zagadnienia te pozostaną w gestii 
autonomicznej uczelni. Jeśli tak, to przełomu nie będzie! Kilka procent uczelni publicznych (optymistycznie patrząc) uporządkuje te procesy w rozsądny sposób, reszta będzie trwała w niewiedzy i nieświadomości. Mówiąc szczerze, nawet obecny stan prawny umożliwia racjonalne zarządzanie własnością intelektualną. Odrobina wysiłku organizacyjnego, wprowadzenie i przestrzeganie stosownych regulaminów i procedur może przynieść dobre rezultaty. Jeśli jednak nie potrafimy efektywnie wprowadzić osiągnięć na polu nauk stosowanych oraz komercjalizacji wyników badań (technologie, patenty, zlecenia dla przemysłu, licencje etc.) do oceny indywidualnej każdego pracownika nauki oraz osiągnięć jednostki (parametryzacja), którą on/ona reprezentuje, nie ma szans na żaden przełom w tej materii.

\section{Zakończenie}

Nowatorska metodologia prac nad przygotowaniem nowej ustawy o szkolnictwie wyższym polegała na wyborze - w trybie konkursu - spośród kilkunastu zgłoszonych propozycji trzech zespołów badawczych (są to trzy grupy ekspertów - Warszawa, Poznań, Kraków), które w 2016 r. przygotowały projekty założeń do reformy. Debata nad tymi założeniami przetoczyła się przez środowisko, również w trakcie konferencji programowych MNiSW, które odbyły się w dziewięciu ośrodkach akademickich w kraju. W sumie był to, i nadal jest, polityczny majstersztyk! Wszelkie odium odważnych/rewolucyjnych postulatów tych trzech zespołów spadało na nie same, resort odgrywa póki co rolę życzliwego obserwatora dyskusji. Od czasu do czasu premier Gowin wrzuca do przestrzeni publicznej kolejne pomysły, postulaty a nawet propozycje rozwiązań, które nie wynikają wprost z powyższych opracowań ani z przebiegu ogólnokrajowej debaty. Sonduje się rynek, sprawdza się reakcje środowiska... A jego opór na wszelkie zmiany jest zatrważający. Jeden z zespołów określił dobitnie prace nad reformą szkolnictwa wyższego słowami: changing universities is like moving a cemetery - hard work and no internal suport... (w wolnym tłumaczeniu: „zmiany na uniwersytetach to jak przenosiny cmentarzy - ciężka praca i żadnej pomocy od zainteresowanych").

Wyniki prac wspomnianych zespołów zostały ogłoszone w lutym 2017 r. Diagnoza obecnego stanu szkolnictwa była podobna, ale już propozycje, tempo i głębia zmian są różne. Kolejny krok należy do resortu, choć trudno sobie wyobrazić konsolidacje tak różnych założeń i rozwiązań. Złośliwi mówią, że tekst nowej ustawy jest już od dawna przygotowany i leży w resorcie, oczekując na jesienną konferencję w Krakowie. Żadna ustawa nie jest bowiem w stanie pomieścić tysięcy różnych, często sprzecznych ze sobą, a zarazem sensownych postulatów. „Ktoś” będzie musiał ponieść odpowiedzialność za ,jedynie słuszny” wybór części propozycji. Bezprecedensowa debata w środowisku dotyczyła wszelkich aspektów sektora nauki i szkolnictwa wyższego w Polsce. Czy zaproponowane w Ustawie 2.0 rozwiązania 
otworzą kolejną debatę - tym razem nad realnie proponowanymi zapisami i czy będzie ona miała jakiekolwiek znaczenie dla ostatecznych zapisów ustawowych? To jest dobre pytanie. Tym bardziej w kontekście wielkiej środowiskowej dyskusji, która odbyła się wcześniej... W każdym razie nikt nie może powiedzieć, że nie było dyskusji i konsultacji...

\section{From One Reform to the Next One}

ABSTRACT. The author presents three issues on-going reforms process of science and higher education sector in Poland. The article focused on the way of choosing presidents (rector), relations between collegial organs and individual personal positions as well as different aspects of technology transfer and commercializations of the research results in economy.

KEYWORDS: science and HE sector, president (rector choice), collegial organs, personal individual positions, technology transfer, commercialization

CYTOWANIE: Guliński, J. (2017). Od reformy do reformy, Nauka i Szkolnictwo Wyższe. 2(50): 279287. DOI: 10.14746/nisw.2017.2.15.

JACEK GULIŃSKI - prof. UAM, dr hab., chemik, wykładowca akademicki. Specjalizuje się w chemii krzemoorganicznej oraz zagadnieniach związanych z transferem innowacji i technologii, polityką innowacyjną, relacjami nauki z gospodarką oraz komercjalizacją wyników prac badawczych. Autor i współautor wielu monografii, publikacji naukowych oraz zgłoszeń patentowych. Profesor Wydziału Chemii na Uniwersytecie im. Adama Mickiewicza w Poznaniu. W 1973 r. otrzymał tytuł magistra chemii (Wydział Chemii UAM), a w 1978 r. inżyniera ogrodnictwa (Akademia Rolnicza, Poznań). W 1983 r. uzyskał stopień doktora nauk chemicznych (Wydział Chemii UAM), a w 1996 r. stopień doktora habilitowanego. W latach 1995-2008 pełnił funkcję zastępcy dyrektora Poznańskiego Parku Naukowo-Technologicznego Fundacji UAM (pierwszego w Polsce), w latach 1999-2005 funkcję prezesa Zarządu Stowarzyszenia Organizatorów Ośrodków Innowacji i Przedsiębiorczości w Polsce, a w latach 2004-2008 - kierownika Uczelnianego Centrum Innowacji i Transferu Technologii UAM. Od września 2008 do stycznia 2012 r. pełnił funkcję prorektora ds. programów europejskich i współpracy z gospodarką na Uniwersytecie im. Adama Mickiewicza w Poznaniu. W latach 2012-2014 jako podsekretarz stanu w Ministerstwie Nauki i Szkolnictwa Wyższego odpowiedzialny był m.in. za politykę rozwoju i innowacyjności, a także sprawy związane ze współpracą nauki z gospodarką oraz programowaniem funduszy europejskich w perspektywie 2014- 2020. Od stycznia 2015 r. pełni funkcję prezesa Zarządu Fundacji Uniwersytetu im. Adama Mickiewicza w Poznaniu oraz dyrektora Poznańskiego Parku Naukowo-Technologicznego Fundacji UAM. Członek Polskiego Towarzystwa Chemicznego oraz Stowarzyszenia Organizatorów Ośrodków Innowacji i Przedsiębiorczości w Polsce. Odznaczony Złotym Krzyżem Zasługi. E-mail: Jacek.Gulinski@ppnt.poznan.pl. 